\title{
KOMPETENSI KOMUNIKASI ANTAR BUDAYA PESERTA PELATIHAN DARI INDONESIA DI AUSTRALIA
}

\author{
Amia Luthfia \\ Jurusan Marketing Communication, Fakultas Komunikasi dan Multimedia, BINUS University \\ Jln. K.H. Syahdan No. 9, Kemanggisan, Palmerah, Jakarta Barat 11480
}

\begin{abstract}
This research studied about intercultural communication competency Indonesians when they study in Australia. Having competency in communicating with different cultures is important in order to avoid intercultural conflict, also to establish effective and proper communication. Although the training participants have different cultural background with Australians, obviously they are competent enough to conduct intercultural communication especially in social formal context. However, in social informal context, they are not competent enough. The training participants are competent in social formal context because they are helped by education setting that accommodative and tolerance towards their weaknesses compared to social informal context.
\end{abstract}

Keywords: intercultural communication, cultures, social formal, social informal

\begin{abstract}
ABSTRAK
Penelitian ini menelaah kompetensi komunikasi antarbudaya orang Indonesia ketika mereka ditugaskan belajar di Australia. Memiliki kompetensi dalam berkomunikasi dengan orang dari budaya yang berbeda sangat penting karena untuk menghindari konflik antar budaya, juga agar komunikasi yang terjadi efektif dan layak. Walaupun para peserta pelatihan memiliki latar belakang budaya yang sangat berbeda dengan orang Australia, ternyata mereka cukup kompeten berkomunikasi antar budaya terutama pada konteks sosial formal. Akan tetapi pada konteks sosial informal, mereka tidak cukup kompeten. Peserta pelatihan dapat cukup kompeten pada konteks sosial formal karena terbantu oleh setting pendidikan yang lebih akomodatif dan toleran terhadap kekurangan-kekurangan mereka dibandingkan pada konteks sosial informal.
\end{abstract}

Kata kunci: komunikasi antarbudaya, budaya, sosial formal, sosial informal 


\section{PENDAHULUAN}

Globalisasi di era digital seperti sekarang ini terasa semakin menyusutkan dunia dan menjadikan dunia semakin tanpa tapal batas. Ditambah dengan semakin canggihnya teknologi komunikasi dan transportasi, orang dari berbagai belahan dunia bisa sangat mudah berkomunikasi dan berinteraksi kapan saja dan dimana saja. Kondisi ini sesuai dengan prediksi Marshall McLuhan puluhan tahun yang lalu yang menyatakan dunia seperti Desa Global (Global Village).

Globalisasi pada kenyataannya mendorong pada terjadinya komunikasi antar budaya yang semakin meningkat pesat, karena orang yang berbeda budaya semakin mudah untuk berkomunikasi. Komunikasi antar budaya dapat terjadi dalam berbagai konteks sosial yang mengandung perbedaan kebudayaan, seperti dalam bidang perusahaan-organisasi, pendidikan, akulturasi imigran, politik, penyesuaian diri pemukim sementara, pengalihan teknologi dan pembangunan (Kim dalam Sunarwinadi, 1993). Dan para ilmuwan sosial mengakui bahwa budaya dan komunikasi tidak dapat dipisahkan. Seperti yang dikatakan oleh Hall (1977) bahwa culture is communication dan communication is culture.

Kebudayaan tidak saja menentukan siapa berbicara dengan siapa, mengenai apa dan bagaimana komunikasi seharusnya berlangsung, tetapi juga mengenai bagaimana pesan sebaiknya dirumuskan, makna dari pesan, serta dalam kondisi dan keadaan bagaimana pesan boleh dan tidak boleh disampaikan, diperhatikan dan ditafsirkan. Tingkah laku komunikasi manusia sebagian besar tergantung pada kebudayaan dimana dia dibesarkan. Dengan kata lain, kebudayaan merupakan landasan bagi komunikasi. Maka kebudayaan yang beraneka ragam, menghasilkan praktek komunikasi yang bervariasi pula (Samovar, Porter \& Jain, 1981).

Pentingnya komunikasi antar budaya di tanah air semakin terasa karena semakin banyaknya perusahaan-perusahaan asing menanamkan modalnya di Indonesia yang sekaligus memperkerjakan karyawan-karyawan asing, semakin banyaknya turis asing, konsultan-konsultan asing, diplomat, pelajar program pertukaran, dan lain-lain. Dan sebaliknya pula, banyak sekali pelajar-pelajar Indonesia yang kuliah dan training di luar negri, serta karyawan-karyawan Indonesia yang bekerja atau ditugaskan di luar negeri.

Sejalan dengan meningkatnya kesadaran akan semakin menyepitnya dunia dan adanya saling ketergantungan global, maka pemahaman antar budaya dan kemampuan berkomunikasi antar budaya menjadi sangat penting. Hanya melalui komunikasi antar budaya yang kompeten, orang dari budaya yang berbeda dapat berkomunikasi dengan efektif dan layak serta dapat memahami satu sama lain di dalam masyarakat global (Chen \& Starosta, 1996).

Agar seseorang kompeten berkomunikasi antar budaya sehingga komunikasinya efektif dan layak, dibutuhkan sikap yang mendukung yaitu tidak berprasangka buruk pada orang dari budaya lain, tidak menganggap bahwa budayanya sendiri yang terbaik (etnosentris), harus berpikiran terbuka, dsb. Selain itu harus memiliki pengetahuan yang cukup tentang budayanya sendiri dan budaya orang lain. Sikap dan pengetahuan ini harus didukung ketrampilan berkomunikasi antar budaya. Seperti trampil dalam berbicara, mendengarkan, membaca dan menulis dengan bahasa setempat, mampu mengekspresikan dan memahami ekspresi non verbal, dapat mengikuti aturan berinteraksi (Kim dalam Sunarwinadi, 1993).

Kemampuan ini sangat penting agar kita dapat survive dalam persaingan global, juga agar tidak terjadi konflik antar budaya yang merugikan. Pemahaman antar budaya dan kompetensi komunikasi antar budaya sangat penting terutama bagi para diplomat, negosiator, pelaku bisnis, profesional, pelajar Indonesia di luar negeri, dan lain-lain. 
Persaingan global juga menuntut kualitas sumber daya manusia Indonesia semakin baik. Untuk itu semakin banyak pelajar dan karyawan yang dikirim untuk belajar di luar negeri. Apakah untuk melanjutkan sekolah atau pun hanya pelatihan singkat beberapa bulan. Dengan berada di negeri orang, para peserta pelatihan dan pelajar-pelajar Indonesia tersebut harus melakukan komunikasi antar budaya. Mereka harus mampu (kompeten) berkomunikasi antar budaya untuk dapat menyesuaikan diri dan untuk membantu mereka dalam mempertahankan kelangsungan hidup secara fisik serta kebutuhan untuk rasa keterlibatan dan dihargai. Oleh karena itu, penelitian ini hendak mengkaji kompetensi (kemampuan) komunikasi antar budaya peserta pelatihan dari Indonesia di Australia.

\section{Kompetensi Komunikasi}

Hammer (1989) menjelaskan konsep kompetensi komunikasi, dimana konsep ini merupakan alat untuk mengukur kualitas komunikasi. Selain itu, pencapaian kemampuan komunikasi diperlukan untuk memenuhi kebutuhan umum manusia, yaitu mengatasi lingkungannya. Kompetensi komunikasi ini juga meliputi penilaian sosial yang dilakukan interaktan terhadap kemampuan dirinya dan orang lain dalam berkomunikasi (Spitzberg \& Cupach dalam Hammer, 1989).

Spitzberg (1994) mendefinisikan kompetensi sebagai kemampuan atau satu set perilaku terampil. Kompetensi ini sangat kontekstual sifatnya. Dalam menilai kompetensi komunikasi digunakan dimensi keberhasilan dan kelayakan. Keberhasilan artinya aturan, norma, dan harapan yang dinilai dari suatu hubungan yang secara signifikan tidak melanggar atau mengganggu. Sedangkan kelayakan adalah keberhasilan dari rewards atau tujuan-tujuan yang dinilai relatif terhadap biaya dan alternatif-alternatif.

Berbagai literatur menempatkan kompetensi komunikasi antar budaya hampir sama dengan kompetensi komunikasi secara umum. Perbedaannya, pada kompetensi komunikasi antar budaya, para pakar memberikan tekanan lebih pada faktor-faktor kontekstual. Jadi, kompetensi komunikasi antar budaya melihat keberhasilan dan kelayakan interaksi antara orang-orang yang mengidentikasikan lingkungan simbolik dan fisik tertentu.

Komunikasi antar budaya terjadi ketika pesan yang harus dipahami, diproduksi oleh anggota dari satu kebudayaan, diproses dan konsumsi oleh anggota dari kebudayaan yang lain. Komunikasi antar budaya adalah komunikasi dimana sumber dan penerimanya berasal dari budaya yang berbeda (Samovar \& Porter, 1994).

\section{Model Kompetensi Komunikasi Antarbudaya}

Chen \& Starosta (1996) menawarkan sebuah model kompetensi komunikasi antar budaya. Model ini bertujuan untuk meningkat kemampuan interaktan dalam memahami, menghargai, mentoleransi dan mengintegrasikan perbedaan budaya, sehingga mereka siap menjadi menjadi anggota masyarakat dunia. Model ini menyajikan sebuah proses transformasional dari saling ketergantungan simetris yang dapat dijelaskan melalui tiga perspektif: (a) affective, atau sensitivitas antar budaya; (b) cognitive, atau kesadaran antar budaya; dan (c) behavioral, atau kecakapan antarbudaya. Ketiga perspektif ini sama-sama penting, tidak dapat dipisahkan dan membentuk gambaran yang holistik dari kompetensi komunikasi antar budaya.

Perspektif sensitivitas antar budaya (affective) berfokus pada emosi personal atau perubahan perasaan yang disebabkan oleh situasi, orang dan lingkungan tertentu (Triandis dalam Chen \& Starosta, 1996). Empat atribut personal yang membangun perspektif ini adalah: (1) self-concept (konsep diri), cara seseorang memandang dirinya; (2) open-mindedness (berpikiran terbuka); (3) nonjudmental attitudes, tidak berprasangka buruk; (4) social relaxation, kemampuan untuk mengungkap hanya sedikit kecemasan emosi dalam komunikasi antar budaya. 
Perspektif kesadaran antar budaya (cognitive) menekankan pada perubahan pemikiran seseorang tentang suatu lingkungan melalui pemahaman perbedaan-perbedaan karakteristik dari budaya dirinya dan orang lain. Di antaranya yaitu, (1) self-awareness atau self-monitoring, kesadaran diri; (2) cultural awareness, kesadaran budaya. Dalam menelaah perspektif ini akan digunakan konsep konsep Hall (dalam Sunarwinadi, 1993), yaitu konsep budaya high-context dan low-context serta monochronic time (M-time) dan polychronic time (P-time). Pada high-context cultures sebagian besar informasi dalam konteks fisik atau diinternalisasikan di dalam orang-orang yang berinteraksi. Sangat sedikit informasi yang berupa pesan-pesan verbal. Pada low-contextt cultures sebagian besar informasi berupa pesan-pesan verbal. Jepang, Korea dan negara-negara Asia lainnya merupakan high-context cultures. Amerika Serikat, Jerman, Swiss dan negara Eropa Barat lainnya adalah low-context cultures. Monochronic time artinya memberikan perhatian pada sesuatu dan melakukan hanya satu hal pada satu waktu. Polychronic time artinya terlibat dengan berbagai hal dalam satu waktu.

Perspektif kecakapan antarbudaya (behavioural) menekankan pada bagaimana untuk bertindak secara efektif di dalam interaksi antar budaya. Kecakapan antar budaya (intercultural adroitness) bertalian erat dengan ketrampilan berkomunikasi. Hal ini meliputi perilaku verbal dan non-verbal yang memberikan interaksi yang efektif. Atribut-atribut yang membangun perspektif ini adalah: (1) message skills, kemampuan untuk menggunakan bahasa orang lain; (2) appropriate selfdisclosure, pengungkapan diri yang layak; (3) behavioral flexibility, kemampuan untuk memilih perilaku yang layak dalam konteks dan situasi yang berbeda; (4) interaction management, kemampuan untuk berbicara dalam percakapan dan untuk memulai dan menghentikan pembicaraan secara layak; dan (5) social skills, empati.

\section{HASIL DAN PEMBAHASAN}

Pada penelitian ini, subyek penelitian adalah sekelompok wanita Indonesia berusia antara 26 sampai 60 tahun, mengikuti pelatihan selama 3 bulan di Adelaide Australia. Sebelum berangkat mereka mengikuti pre-departure training selama 3 bulan di Jakarta. Selama di Jakarta, mereka memperoleh pelajaran bahasa Inggris dan berbagai materi tentang kondisi serta budaya Australia. Kemudian selama di Australia, mereka berada dalam lingkungan pendidikan dan mendapatkan berbagai fasilitas yang sangat mendukung kegiatan mereka.

Peneliti mengamati peserta pelatihan dalam dua konteks sosial, yaitu formal dan informal. Konteks sosial formal berada dalam setting di dalam ruang kelas pelatihan, seminar-seminar, kunjungan lapangan dan jamuan makan. Orang-orang Australia yang berkomunikasi dengan peserta pelatihan dalam konteks sosial formal ini sebagian besar adalah guru, mentor, pelatih, dan orang-orang dari lingkungan pendidikan di tingkat kejuruan di Australia. Sedang pada konteks sosial informal, para peserta berada dalam setting kehidupan sehari-hari seperti di pusat perbelanjaan, di restoran, di asrama, di kendaraan umum dan tempat-tempat publik lainnya.

Para peserta pelatihan dari Indonesia dapat dikatakan cukup kompeten berkomunikasi antar budaya dengan orang Australia pada konteks sosial formal, karena memenuhi sebagian besar standar kompetensi komunikasi antar budaya yang dikemukakan oleh Chen \& Starosta. Atribut-atribut yang dapat dipenuhi para peserta pelatihan adalah proses affective, cognitive, dan behavioural.

Atribut-atribut affective process adalah: (1) self concept, peserta pelatihan memandang diri mereka adalah orang-orang yang mampu berbahasa Inggris dan mampu berkomunikasi dengan baik dengan orang Australia. Mereka cukup percaya diri untuk berhadapan dengan orang Australia, artinya mempunyai self esteem yang cukup tinggi. Hal ini mungkin disebabkan oleh latar belakang pendidikan mereka yang cukup tinggi dan semuanya memiliki karir pekerjaan yang dapat dibanggakan. (2) Open 
mindedness, peserta pelatihan bisa menerima ide-ide dan pendapat yang dikemukakan oleh orang Australia. Open mindedness ini juga diakui oleh orang Australia, bahwa kelompok ini dapat dengan baik melihat dan menerima pandangan orang lain. (3) Non judgmental attitude, kelompok ini dapat memahami semua perbedaan antara orang Australia dan Indonesia. Mereka tidak memandang orang Australia itu buruk, justru sebaliknya, mereka menganggap orang Australia itu ramah, bersahabat dan penolong. (4) Social relaxation, peserta pelatihan dapat menyembunyikan dengan baik kecemasan mereka. Mereka selalu terlihat ceria di mata orang Australia. Kemampuan menyembunyikan kecemasan ini membantu mereka untuk tetap dapat berkomunikasi dengan baik.

Atribut cognitive process adalah cultural awareness, yaitu para peserta pelatihan memiliki pengetahuan antar budaya yang cukup. Mereka memperolehnya pada saat pre-departure training dan dari hasil pengamatan serta interaksi mereka dengan orang Australia. Pengetahuan antar budaya ini mereka aplikasinya selama di Australia, antara lain tepat waktu, ketat mengikuti jadwal dan normanorma orang Australia.

Atribut-atribut behavioral process yaitu: (1) message skill, mereka cukup lancar berbahasa Inggris lisan dan tulisan. Hal ini ditunjukkan orang Australia mengerti apa yang mereka sampaikan baik lisan maupun tulisan. (2) Interaction management, mereka dapat membangun pembicaraan dengan baik, memulai dan mengakhirinya. Mereka juga dapat berkomunikasi secara bergiliran sesuai dengan aturan orang Australia. (3) Behavioral flexibility, para peserta pelatihan dapat memilah-milah perilaku yang cocok dengan situasi dan individu yang berinteraksi dengan mereka. Perilaku dalam situasi formal berbeda ketika informal. (4) Social skill, mereka cukup berempati ketika berkomunikasi dengan orang Australia. Juga menunjukkan sikap menghargai dan memperhatikan lawan bicara.

Dari seluruhan atribut kompetenti komunikasi antar budaya yang dikemukakan oleh Chen dan Starosta, terdapat 2 atribut yang tidak dapat dipenuhi oleh para peserta pelatihan yaitu self monitoring yang berada di dalam naungan cognitive process dan appropriate self disclosure yang berada di bawah naungan behavioral process. Mereka tidak dapat memenuhi atribut self monitoring ditunjukkan dengan mereka tidak dapat mengontrol dan memonitor perilaku mereka agar sesuai dengan pengetahuan mereka dalam berkomunikasi antar budaya. Perilaku mereka yang tidak layak pada budaya Australia adalah tidak mengikuti secara utuh setiap kata yang disampaikan oleh lawan bicara mereka dan beberapa orang sering berbisik-bisik di dalam kelas.

Dalam hal appropriate self disclosure, mereka tidak dapat memenuhi atribut ini karena mereka tidak cukup terbuka mengungkapkan diri mereka dan tidak cukup layak dalam mengungkapkannya. Seringkali mereka mengatakan "yes" tapi ditunjukkan dengan perilaku "no" (pesan ambigu) atau dengan bahasa tubuh yang membingungkan orang Australia. Perilaku ini sangat sering terlihat ketika berhubungan dengan pemahaman materi pelatihan dan pengerjaan tugas-tugas yang diberikan. Atribut ini tidak dapat dipenuhi disebabkan latar belakang budaya high-context peserta pelatihan yang menganggap orang Australia dapat menangkap keraguan nada bicara mereka ketika menyatakan "yes" dan ekspresi wajah yang masih belum paham. Sedangkan orang Australia berasal dari budaya low-context, mereka tidak terampil membaca pesan non verbal dari orang-orang berlatar budaya high-context.

Pada konteks sosial informal, kompetensi komunikasi antar budaya peserta pelatihan adalah tidak cukup kompeten. Ternyata, pada konteks informal mereka cukup sering mengalami kegagalan dalam berkomunikasi. Message skill mereka terlihat kurang baik terutama pada kemampuan mendengarkan. Mereka seringkali terlihat tidak dapat menangkap dan memahami kata-kata orang Australia. Mereka menganggap orang Australia sangat cepat berbicara dan dengan aksen yang sulit untuk dipahami. Hal ini berdampak pada interaction management komunikasi mereka. Mereka tidak dapat membangun topik pembicaraan dengan baik. 
Atribut self monitoring dan cultural awareness juga tidak ditemukan pada konteks sosial informal ini. Mereka tidak dapat mengontrol diri untuk tidak memotong pembicaraan dan mendengarkan dengan baik ketika orang Australia sedang berbicara. Mereka juga tidak dapat mengontrol diri untuk tidak berdiskusi sendiri, berbicara berbarengan dalam satu waktu atau memberi komentar yang tidak diperlukan. Tentunya hal tersebut adalah perilaku yang tidak layak pada budaya Australia. Padahal mereka punya cukup pengetahuan tentang hal tersebut.

Dapat terpenuhinya sebagian besar atribut kompetensi komunikasi antar budaya pada konteks sosial formal bisa jadi disebabkan karena orang-orang Australia yang berkomunikasi dengan peserta pelatihan adalah orang-orang dari lingkungan pendidikan yang cenderung akomodatif, apresiatif dan menganggap peserta adalah tamu atau pelajar. Sedangkan lingkungan informal tidak setoleran lingkungan formal.

Latar belakang budaya collectivistic ternyata cukup mempengaruhi atribut self monitoring dan interaction management. Ikatan kelompok yang sangat kuat membuat mereka cenderung untuk selalu melakukan kegiatan bersama-sama. Ketika mereka di dalam kelompoknya mereka cenderung sulit untuk mengontrol diri dan mengatur perbincangan sesuai dengan aturan budaya Australia—only one person should talk in a time-walaupun mereka sudah mengetahui aturan ini.

Atribut cultural awareness yang tidak dapat dipenuhi peserta pelatihan dan dianggap tidak layak oleh orang Australia ternyata dipengaruhi oleh budaya collective dan polichronic time. Peserta pelatihan memiliki kebiasaan menanyakan pendapat orang lain atas pilihannya serta lama berdiskusi untuk menentukan pilihan yang baik untuk dirinya. Perilaku ini seringkali menjengkelkan orang Australia yang berbudaya monochronic-time dan individualistik. Waktu sangat penting bagi mereka dan pilihan pribadi diputuskan sendiri.

Peneliti menilai beberapa atribut dari Model Kompetensi Komunikasi Antar Budaya yang dikemukakan Chen dan Starosta terasa tidak mengena dengan penelitian ini karena sulit untuk dilihat. Kesulitan ini dialami karena peneliti dan subyek penelitian yang diamati berasal dari budaya timur sedangkan ukuran yang digunakan berasal dari budaya barat. Misalnya saja atribut interaction management terutama pada tahap membangun dan mengembangkan topik pembicaraan. Setiap budaya memiliki gaya komunikasi tersendiri yang berbeda dengan budaya lain. Apa saja yang menjadi topik pada small talk dan big talk; bagaimana cara berpindah dari satu topik pembicaraan ke topik yang lain; pesan-pesan verbal dan non verbal yang sebaiknya digunakan; tentunya berbeda pada budaya Indonesia dan Australia. Begitu pula dengan atribut appropriate self disclosure, hal-hal yang layak diungkap di budaya Indonesia belum tentu layak diungkap di budaya Australia.

Peneliti menyarankan patut dilakukan penelitian lebih lanjut tentang kompetensi komunikasi antar budaya dari perspektif budaya Indonesia atau dari perspektif budaya timur. Dalam hal praktis, sangat penting dilakukannya pre-departure training bagi orang-orang yang akan belajar dan bekerja di luar negeri.

\section{DAFTAR PUSTAKA}

Chen, G. M., \& Starosta, W. J. (1996). Intercultural communication competence: A synthesis. In B. R. Burleson, (Ed.), Communication Yearbook 19. USA: Internation Comm.

Hall, E. T. (1977). Beyond culture. USA: Dell. 
Hammer, M. R. (1989). Intercultural communication competence. In M. K. Asante \& W. B. Gudykunst (Eds.), Handbook of international and intercultural communication. New York: Sage.

Samovar, L. A., \& Porter, R. E. (1994). Intercultural communication: A reader (7th ed.). New York: International Thomson.

Samovar, L. A., Porter, R. E., \& Jain, N. C. (1981). Understanding intercultural communication. California: Wadsworth.

Spitzberg, B. H. (1996). A model of intercultural communication competence. In L. A. Samovar \& R. E. Porter (Eds.), Intercultural communication. A reader (7th ed.). New York: International Thomson.

Sunarwinadi, I. R. (1993). Komunikasi sosial dalam adaptasi antar budaya. Disertasi tidak dipublikasikan. Jakarta: Universitas Indonesia. 